\title{
Evaluation of a Medically Supervised Concussion Protocol for Youth Hockey in Canada
}

\author{
Michael J. Ellis, Jeff Leiter, Dean M. Cordingley, Karen Reimer, James Koenig, \\ Kelly F. Russell
}

\begin{abstract}
Objectives: The objective of this study was to evaluate the feasibility and implementation of a standardized medically supervised concussion protocol established between a city-wide AAA hockey league and a multi-disciplinary concussion program. Methods: We conducted a retrospective review of injury surveillance, clinical and healthcare utilization data from all athletes evaluated and managed through the Winnipeg AAA Hockey concussion protocol during the 2016-2017 season. We also conducted post-season email surveys of head coaches and parents responsible for athletes who competed in the same season. Results: During the 2016-2017 season, 28 athletes were evaluated through the medically supervised concussion protocol, with two athletes undergoing evaluation for repeat injuries (a total of 30 suspected injuries and consultations). In all, 96.7\% of the athletes managed through the concussion protocol were captured by the league-designated Concussion Protocol Coordinator and $100 \%$ of eligible athletes underwent complete medical follow-up and clearance to return to full hockey activities. Although $90 \%$ of responding head coaches and $91 \%$ of parents were aware of the concussion protocol, survey results suggest that some athletes who sustained suspected concussions were not managed through the protocol. Head coaches and parents also indicated that athlete education and communication between medical and sport stakeholders were other elements of the concussion protocol that could be improved. Conclusion: Successful implementation of a medically supervised concussion protocol for youth hockey requires clear communication between sport stakeholders and timely access to multi-disciplinary experts in traumatic brain and spine injuries. Standardized concussion protocols for youth sports may benefit from periodic evaluations by sport stakeholders and incorporation of national guideline best practices and resources.
\end{abstract}

RÉSUMÉ: Évaluation d'un protocole de gestion des commotions cérébrales destiné à des jeunes hockeyeurs canadiens et encadré médicalement. Objectifs: Évaluer la faisabilité et la mise en œuvre d'un protocole standardisé de gestion des commotions cérébrales établi entre une ligue de hockey de calibre AAA à l'échelle d'une ville et un programme multidisciplinaire de gestion des commotions cérébrales. Méthodes: Nous avons mené une analyse rétrospective des données liées à tous les athlètes évalués et pris en charge dans le cadre du protocole de gestion des commotions cérébrales adopté par la ville de Winnipeg pour son calibre AAA, et ce, durant la saison 2016-2017. Mentionnons que ces données se rapportaient spécifiquement au suivi des blessures signalées ainsi qu'aux soins cliniques prodigués. À la fin de la saison, nous avons aussi effectué un sondage par courriel ciblant les entraîneurs et les parents responsables des jeunes athlètes ayant compétitionné. Résultats: Durant la saison 2016-2017, 28 athlètes ont été évalués dans le cadre du protocole de gestion des commotions cérébrales. Deux athlètes ont également été soumis à une évaluation en raison de blessures à répétition, ce qui a donné un total de 30 individus, chez qui l'on soupçonnait des lésions, ayant consulté. Dans l'ensemble, 96,7 \% des athlètes visés par ce protocole ont été dépistés par le coordonnateur de la ligue ayant été nommé pour en assurer le suivi. De plus, $100 \%$ des athlètes admissibles ont bénéficié d'un suivi médical complet et ont recommencé à jouer au hockey, sans contre-indications, moyennant une autorisation. Bien que $90 \%$ des entrâneurs-chefs et $91 \%$ des parents ayant répondu au sondage étaient au courant de l'existence de ce protocole, nos résultats suggèrent néanmoins que certains athlètes chez qui l'on suspectait une commotion cérébrale n'ont pas été pris en charge dans le cadre du protocole. Ces mêmes entraîneurs-chefs et ces mêmes parents ont aussi indiqué que la sensibilisation des athlètes, de même que la communication établie avec les intervenants médicaux et sportifs, sont d'autres aspects du protocole qui pourraient être améliorés. Conclusions: La mise en œuvre réussie de protocoles de gestion des commotions cérébrales destinés à de jeunes hockeyeurs et encadrés médicalement exige une bonne communication entre les parties prenantes du monde du sport ainsi qu'un accès en temps opportun à des équipes multidisciplinaires spécialisées dans les lésions traumatiques cérébrales et dans celles affectant la colonne vertébrale. On pourrait même ajouter que les protocoles standardisés de ce type visant l'ensemble des sports pratiqués par les jeunes pourraient bénéficier d'évaluations périodiques conduites par les intervenants sportifs et de l'adoption de lignes directrices nationales fondées sur les meilleures pratiques en vigueur.

Keywords: Sports-related concussion, Hockey, Concussion protocol, Youth, Public health, Canada

doi:10.1017/cjn.2018.30

Can J Neurol Sci. 2018; 45: 424-431

From the Department of Surgery, University of Manitoba, Winnipeg, Manitoba, Canada (MJE, JL); Department of Pediatrics and Child Health, University of Manitoba, Winnipeg,

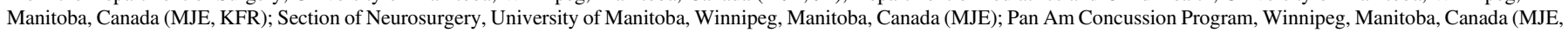

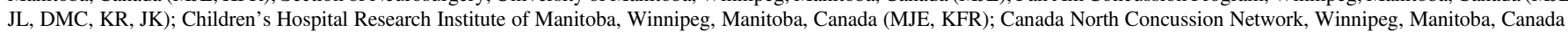
(MJE, JL, DMC, KR, JK, KFR); Pan Am Clinic Foundation, Winnipeg, Manitoba, Canada (JL, DMC); Department of Rehabilitation Sciences, University of Manitoba, Winnipeg, Manitoba, Canada (KR); Department of Diagnostic Imaging, University of Manitoba, Winnipeg, Manitoba, Canada (JK).

Received December 15, 2017. Final Revisions Submitted March 2, 2018. Date of Acceptance March 12, 2018

Correspondence to: Dr. Michael J. Ellis, Pan Am Clinic, Pan Am Concussion Program, 75 Poseidon Bay, Winnipeg, MB, Canada R3M 3E4. Email: mellis3@panamclinic.com 
Hockey is one of the most popular sports played by Canadian youth. During the 2015-2016 season, over 500,000 athletes were registered in organized hockey across Canada. ${ }^{1}$ Among the most common injuries sustained in competitive youth hockey is concussion, ${ }^{2-4}$ a form of traumatic brain injury (TBI) that results in clinical symptoms that typically resolve within 1-4 weeks. 5,6 Studies suggest that optimizing the clinical care of pediatric concussion patients requires early injury recognition and multidisciplinary management by a team of healthcare professionals with expertise in traumatic brain and spine injury. ${ }^{7,8}$

To help improve the health and safety of its athletes, several professional sport leagues have established standardized concussion protocols that outline measures that must be taken to ensure proper recognition, medical evaluation, and clearance of those who sustain a suspected concussion. ${ }^{9}$ More recently, Canadian government, sport, and health stakeholders have recommended that organizations operating youth sport activities with a risk of concussion also establish similar standardized concussion protocols for their athletes. ${ }^{10,11}$ Despite these advances and recommendations, the authors are not aware of any published reports evaluating the feasibility and implementation of a standardized medically supervised concussion protocol for any youth sport in Canada.

Accordingly, we present a single-season (2016-2017) review of injury surveillance, as well as clinical and healthcare utilization data, for all athletes evaluated through a standardized concussion protocol established between a city-wide AAA hockey organization and a provincial multi-disciplinary pediatric concussion program. We also present the results of post-season surveys from coach and parent stakeholders who were responsible for athletes competing during the same season. Drawing from this experience and recently published national guidelines, we highlight several key elements that should be considered by sport stakeholders when developing standardized concussion protocols for youth sports in Canada.

\section{MethodS}

\section{Standardized Concussion Protocol and Participants}

Beginning in the 2013-2014 season, Winnipeg AAA Hockey and the Pan Am Concussion Program established a standardized medically supervised concussion protocol for all athletes. Winnipeg AAA Hockey is the governing body responsible for the organization and operation of a youth minor hockey league that typically includes 250-280 male Bantam (age 12-14 years) and Midget (age 15-17 years) athletes playing full contact hockey at the highest competitive level in Winnipeg, Manitoba, Canada. The Pan Am Concussion Program is a provincial governmentfunded clinical program that provides multi-disciplinary evaluation and management of children and adolescents with concussion and other forms of TBI throughout Manitoba. Outside of the Winnipeg AAA Hockey concussion protocol, patient access to the pediatric concussion program requires a referral from a physician. However, patients who sustained repeat injuries after discharge from the pediatric concussion program can be seen without a physician referral. All patients referred to this pediatric concussion program undergo medical assessment and Return-to-Sport medical clearance by a single neurosurgeon who has access to a multi-disciplinary team of experts in neuropsychology, vestibular and cervical spine physiotherapy, exercise science, and other subdisciplines, as well as off-site diagnostic imaging (i.e., radiography, magnetic resonance imaging, MRI). ${ }^{7}$
The primary objective of the Winnipeg AAA Hockey concussion protocol was to provide clear instructions to athletes, parents, and coaches regarding measures that must be taken to ensure standardized medical evaluation, follow-up, and clearance of all Winnipeg AAA Hockey athletes who sustained a suspected concussion or more serious head or neck injury during a game or practice. On the basis of feedback from sport and medical stakeholders obtained over the first 3 years of implementation, the original concussion protocol underwent several minor revisions. In summary, the 2016-2017 Winnipeg AAA Hockey concussion protocol specified that all athletes with a suspected serious head or spine injury undergo on-ice evaluation by emergency medical services and referral to Winnipeg's Health Sciences Children's Hospital (HSC-CH). All athletes who sustained a suspected concussion resulting in non-life-threatening acute symptoms were to be immediately removed from play and evaluated at $\mathrm{HSC}-\mathrm{CH}$ or the nearest hospital. After initial emergency department assessment, these patients were instructed to seek follow-up care at the Pan Am Concussion Program. Athletes who developed delayed concussion symptoms following an injury could receive direct access to the Pan Am Concussion Program. In the case of athletes who sustained a suspected concussion and had on-site access to a medical doctor (MD) or athletic therapist, sideline assessment was to be carried out using the Sport Concussion Assessment Tool 3 (SCAT3) to document initial neurological status. However, because SCAT3 testing can be normal in adolescents with an acute concussion, ${ }^{12}$ all athletes with a suspected concussion were to be referred for medical assessment irrespective of the SCAT3 results. For each athlete removed from play for a suspected concussion or more serious head or spine injury, the athlete's parent, coach, or trainer was instructed to contact the designated Winnipeg AAA Hockey Concussion Protocol Coordinator who was responsible for injury surveillance and facilitating referrals for initial assessment and follow-up care at the Pan Am Concussion Program. In cases in which the pediatric concussion program was notified directly of an injured Winnipeg AAA Hockey player, the athlete's parents were advised to report the injury to the Winnipeg AAA Hockey Concussion Protocol Coordinator before the athlete being scheduled for clinical assessment. Before returning to full contact and/or game play, all athletes were required to obtain medical clearance by a single neurosurgeon and were not to be allowed to return to play without a written medical clearance letter issued by the pediatric concussion program.

To ensure that all parents and coaches were informed of the standardized concussion protocol, a parent for each athlete was required to attend a pre-season orientation session held by Winnipeg AAA Hockey. The standardized concussion protocol was provided to each head coach before the start of the season and the protocol was posted online on both the Winnipeg AAA Hockey and Pan Am Concussion Program websites. Last, all head coaches were required to attend a pre-season coaches meeting that included a presentation on concussion and the concussion protocol.

\section{Clinical Assessment and Definitions}

Athletes referred to the Pan Am Concussion Program through the concussion protocol underwent clinical assessment by a single neurosurgeon. All athletes completed the Post-Concussion Symptom Scale (PCSS), which is a valid and reliable measure of concussion symptoms, ${ }^{13,14}$ at all clinical appointments. The diagnosis of 
concussion was made by the neurosurgeon based on the definition set forth by the International Consensus Statement on Concussion in Sport. ${ }^{12}$ Diagnostic imaging and referrals to other multi-disciplinary team members were arranged based on the clinical discretion of the neurosurgeon. In general, patients were deemed clinically recovered when they were asymptomatic at rest, were tolerating full-time school without symptoms, had a normal neurological examination, and had successfully completed the graduated Return-to-Sport protocol set forth by the 4th International Consensus Statement on Concussion in Sport. ${ }^{12}$ In select cases, assessment of clinical recovery was supplemented by the use of graded aerobic treadmill testing at the discretion of the treating neurosurgeon. ${ }^{15}$ Written medical clearance was provided by the neurosurgeon to athletes before a return to full contact and/or full game play.

In some cases, athletes were referred through the concussion protocol for precautionary reasons (a high-velocity body-check that resulted in no symptoms, development of non-specific symptoms unrelated to any head injury) where a definitive diagnosis of concussion could not be made based on the results of the clinical history, physical examination, and other tests (i.e., graded aerobic treadmill testing). These patients were managed on an individualized basis and also received medical clearance before returning to full contact practice and/or game play.

\section{Injury Surveillance}

During the 2016-2017 season, the Winnipeg AAA Hockey Concussion Protocol Coordinator maintained a list of athletes who reported concussions and were managed through the concussion protocol during the 2016-2017 season. At the end of the season, injury surveillance data from the Concussion Protocol Coordinator was cross-referenced with medical records at the Pan Am Concussion Program to confirm that athletes who reported their injuries were indeed evaluated and received final medical clearance to return to full contact practices and/or game play. In addition, a medical records search of all Winnipeg AAA Hockey players evaluated during the 2016-2017 season was also conducted to determine whether any players were evaluated at the Pan Am Concussion Program but did not report their injury to the Winnipeg AAA Hockey Concussion Protocol Coordinator.

\section{Coach and Parent Surveys}

Electronic surveys were sent to available email addresses obtained from Winnipeg AAA Hockey for all 14 head coaches and one parent of 233 of the 272 players who participated in the 2016-2017 season. The purpose of these surveys was to assess compliance with the standardized concussion protocol during the 2016-2017 season, to obtain coach and parent feedback on awareness and communication related to the concussion protocol, and to obtain their general perspective on concussion protocols and awareness. Electronic surveys were emailed to coaches and parents monthly over a 4-month period.

\section{Statistical Analysis and Ethical Approval}

The characteristics of the athletes were presented as means with standard deviations (or medians with intraquartile ranges if data were not normally distributed) or percentages. The results from the surveys were tabulated. All statistical analyses were conducted using the STATA v13.0 statistics package. Institutional ethics approval was obtained from the University of Manitoba for this study.

\section{Results}

\section{Clinical Data}

During the 2016-2017 season, 28 athletes were evaluated through the medically supervised concussion protocol, with two athletes undergoing evaluation for repeat injuries (a total of 30 suspected injuries and consultations). During the season, 29/30 (96.7\%) injuries were reported to the Winnipeg AAA Hockey Concussion Protocol Coordinator. The one injury not reported directly to the coordinator occurred in a patient who sustained a repeat injury during the same season. Of those who were managed through the standardized concussion protocol, the mean age was 14.42 years (ranging from 12 to 17 years) including 15 male Bantam and 13 male Midget athletes. Among the 28 athletes who were evaluated through the protocol, $12(42.9 \%)$ had a history of previous concussion. In this cohort, 29 of the 30 suspected injuries occurred during hockey-related activities, including 22 that occurred during game play, three that occurred during practice, and four that occurred during an unspecified hockey-related activity. One athlete sustained a non-sports-related injury secondary to a fall down the stairs. Six patients underwent evaluation in the emergency department before initial assessment at the pediatric concussion program. The mean number of days from injury to clinical assessment at the pediatric concussion program for all injuries was 2.33 days (SD: 1.5). On the basis of clinical assessment by the neurosurgeon, a definitive diagnosis of concussion was made in 23/30 (76.7\%) consultations, including two athletes who sustained two concussions in the same season. The median initial PCSS score among athletes diagnosed with a concussion at the time of initial assessment was 10 (intraquartile range 1-15). At the time of assessment, five athletes diagnosed with concussion were also diagnosed with co-incident whiplashtype cervical spine injuries and one was diagnosed with post-traumatic benign paroxysmal positional vertigo. Diagnostic imaging resources utilized by this cohort included routine cervical spine radiographs (three patients), and CT, MRI, and flexionextension radiographs of the cervical spine (one patient). Multidisciplinary consultations that were arranged to help assist with management of these 30 injuries included referral to an exercise physiologist for graded aerobic treadmill testing (11 patients); referral to a vestibular physiotherapist (one patient); referral to a cervical spine physiotherapist (two patients); and consultation with a musculoskeletal radiologist (one patient). Among the athletes who were initially evaluated through the standardized concussion protocol, $27 / 28(96.4 \%)$ were medically cleared to return to play during the same season. The mean number of days from initial injury to final medical clearance among athletes with a diagnosed definitive concussion was 12.71 days (SD: 5.71). Among the two athletes who sustained repeat concussions during the season, one athlete sustained a repeat concussion $\sim 1$ month after the initial injury. Clinical recovery in this athlete was documented at 28 days post injury, and return to play was not considered because the athlete's season had ended. The other athlete sustained a repeat concussion $\sim 2.5$ months after the initial injury. Clinical recovery in this athlete was documented 11 days post injury; however, the athlete was advised to take the rest of the season off owing to the potential risk of repeat injury. 
One patient underwent initial assessment for a suspected concussion at an emergency department and was discharged home without medical follow-up after undergoing routine radiographs and CT imaging of the cervical spine. The patient was evaluated through the concussion protocol the following day where the patient was found to have isolated neck pain, no other concussionlike symptoms, and a normal neurological examination. The previously obtained diagnostic imaging studies were reviewed by the neurosurgeon and a musculoskeletal radiologist and an urgent MRI and flexion-extension radiographs of the cervical spine were arranged that confirmed the presence of a previously unrecognized T1 vertebral body compression fracture. The patient was withheld from hockey for the remainder of the season and managed conservatively.

\section{Survey Data}

Completed surveys were received from 10/14 (71.4\%) head coaches and 123/233 (52.8\%) parents. The results are summarized in Tables 1 and 2.

\section{Table 1: Post-season survey results for head coaches}

\begin{tabular}{|c|c|c|}
\hline Question & Responses & $\begin{array}{c}\text { Number } \\
n=10(\%)\end{array}$ \\
\hline $\begin{array}{l}\text { Prior to the 2016-2017 Winnipeg AAA Hockey } \\
\text { season, were you informed that there was a } \\
\text { concussion protocol in place to help manage } \\
\text { athletes who sustained a suspected concussion } \\
\text { during the season? }\end{array}$ & $\begin{array}{l}\text { Yes } \\
\text { No } \\
\text { Blank }\end{array}$ & $\begin{array}{l}9(90) \\
0(0) \\
1(10)\end{array}$ \\
\hline $\begin{array}{l}\text { Prior to the 2016-2017 Winnipeg AAA Hockey } \\
\text { season, did you attend the pre-season coaches } \\
\text { meeting that outlined details of the 2016-2017 } \\
\text { Winnipeg AAA Hockey Concussion Protocol? }\end{array}$ & $\begin{array}{l}\text { Yes } \\
\text { No } \\
\text { Missing }\end{array}$ & $\begin{array}{l}9(90) \\
0(0) \\
1(10)\end{array}$ \\
\hline $\begin{array}{l}\text { For athletes with a suspected concussion sustained } \\
\text { during the Winnipeg AAA hockey season and } \\
\text { returned to Winnipeg AAA hockey, did all } \\
\text { athletes provide you with a doctor's note that } \\
\text { medically cleared them to return to full game } \\
\text { play? }\end{array}$ & $\begin{array}{l}\text { Yes } \\
\text { No } \\
\text { Missing }\end{array}$ & $\begin{array}{l}8(80) \\
0(0) \\
2(20)\end{array}$ \\
\hline $\begin{array}{l}\text { After sustaining a suspected concussion, please } \\
\text { indicate which healthcare professionals } \\
\text { provided you with a doctor's note to medically } \\
\text { clear your athlete to return to full game play. }\end{array}$ & $\begin{array}{l}\text { Pan Am Con- } \\
\text { cussion Program } \\
\text { Family } \\
\text { Physician/ } \\
\text { Pediatrician } \\
\text { Missing }\end{array}$ & $\begin{array}{l}8(80) \\
0(0) \\
2(20)\end{array}$ \\
\hline $\begin{array}{l}\text { To your knowledge, did any child who underwent } \\
\text { medical assessment for a suspected concussion } \\
\text { sustained during Winnipeg AAA return to full } \\
\text { game play without providing you with a } \\
\text { doctor's note indicating they had received } \\
\text { medical clearance to return to play? }\end{array}$ & $\begin{array}{l}\text { Yes } \\
\text { No } \\
\text { Missing }\end{array}$ & $\begin{array}{l}0(0) \\
8(80) \\
2(20)\end{array}$ \\
\hline $\begin{array}{l}\text { Overall, please rate the communication between } \\
\text { Winnipeg AAA Hockey and the parents and } \\
\text { coaches regarding the Winnipeg AAA Hockey } \\
\text { Concussion Protocol }\end{array}$ & $\begin{array}{l}\text { Excellent } \\
\text { Very good } \\
\text { Good } \\
\text { Fair } \\
\text { Poor } \\
\text { Blank }\end{array}$ & $\begin{array}{l}1(10) \\
2(20) \\
5(50) \\
2(20) \\
0(0) \\
0(0)\end{array}$ \\
\hline $\begin{array}{l}\text { Overall, please rate the communication between } \\
\text { the Pan Am Concussion Program and the } \\
\text { coaches regarding what activities athletes with a } \\
\text { suspected concussion were cleared to } \\
\text { participate in }\end{array}$ & $\begin{array}{l}\text { Excellent } \\
\text { Very good } \\
\text { Good } \\
\text { Fair } \\
\text { Poor } \\
\text { Blank }\end{array}$ & $\begin{array}{l}1(10) \\
3(30) \\
1(10) \\
4(40) \\
0(0) \\
1(10)\end{array}$ \\
\hline
\end{tabular}

Table 1: Continued

\begin{tabular}{c|c|c}
\hline Question & Responses & $\begin{array}{c}\text { Number } \\
\boldsymbol{n}=\mathbf{1 0}(\mathbf{\%})\end{array}$ \\
\hline $\begin{array}{c}\text { Overall, do you think the Winnipeg AAA Hockey } \\
\text { Concussion Protocol has improved the safety of } \\
\text { children playing Winnipeg AAA Hockey? }\end{array}$ & $\begin{array}{c}\text { Yes } \\
\text { Undecided }\end{array}$ & $\begin{array}{c}8(80) \\
2(20)\end{array}$ \\
\hline $\begin{array}{c}\text { Based on your experience, do you think your } \\
\text { Winnipeg AAA athletes receive enough }\end{array}$ & Yes & $7(70)$ \\
education on concussions? & No & $1(10)$ \\
$2(20)$
\end{tabular}

Table 2: Post-season survey results for parents

\begin{tabular}{|c|c|c|}
\hline $\begin{array}{l}\text { Questions answered by all responding parents } \\
(n=123)\end{array}$ & Responses & $\begin{array}{c}\text { Number } \\
n=123(\%)\end{array}$ \\
\hline $\begin{array}{l}\text { Prior to the 2016-2017 Winnipeg AAA Hockey } \\
\text { season, were you informed that there was a } \\
\text { concussion protocol in place to help manage } \\
\text { athletes who sustained a suspected concussion } \\
\text { during the season? }\end{array}$ & $\begin{array}{l}\text { Yes } \\
\text { No } \\
\text { Blank }\end{array}$ & $\begin{aligned} 112 & (91.1) \\
10 & (8.1) \\
1 & (0.8)\end{aligned}$ \\
\hline $\begin{array}{l}\text { Overall, please rate the communication between } \\
\text { Winnipeg AAA Hockey and the parents and } \\
\text { coaches regarding the Winnipeg AAA Hockey } \\
\text { Concussion Protocol. }\end{array}$ & $\begin{array}{l}\text { Excellent } \\
\text { Very good } \\
\text { Good } \\
\text { Fair } \\
\text { Poor } \\
\text { Blank }\end{array}$ & $\begin{array}{c}15(12.2) \\
36(29.3) \\
43(35.0) \\
21(17.1) \\
2(1.6) \\
6(4.9)\end{array}$ \\
\hline $\begin{array}{l}\text { Overall, do you think the Winnipeg AAA Hockey } \\
\text { Concussion Protocol has improved the safety for } \\
\text { children playing Winnipeg AAA Hockey? }\end{array}$ & $\begin{array}{l}\text { Yes } \\
\text { No } \\
\text { Undecided } \\
\text { Blank }\end{array}$ & $\begin{aligned} 76 & (61.8) \\
7 & (5.7) \\
27 & (22.0) \\
13 & (10.6)\end{aligned}$ \\
\hline $\begin{array}{l}\text { Based on your experience, do you think Winnipeg } \\
\text { AAA athletes receive enough education on } \\
\text { concussions? }\end{array}$ & $\begin{array}{l}\text { Yes } \\
\text { No } \\
\text { Undecided } \\
\text { Blank }\end{array}$ & $\begin{array}{l}56(45.5) \\
25(20.3) \\
26(21.1) \\
16(13.0)\end{array}$ \\
\hline $\begin{array}{l}\text { Based on your experience, do you think that all } \\
\text { organized youth sports in Manitoba should have a } \\
\text { standardized concussion protocol? }\end{array}$ & $\begin{array}{l}\text { Yes } \\
\text { No } \\
\text { Undecided } \\
\text { Blank }\end{array}$ & $\begin{aligned} 97 & (78.9) \\
4 & (3.3) \\
7 & (5.7) \\
15 & (12.2)\end{aligned}$ \\
\hline $\begin{array}{l}\text { Based on your experience, do you think that all } \\
\text { children with a suspected concussion should be } \\
\text { evaluated by a medical doctor? }\end{array}$ & $\begin{array}{c}\text { Yes } \\
\text { No } \\
\text { Undecided } \\
\text { Blank }\end{array}$ & $\begin{array}{c}105(85.4) \\
8(6.5) \\
0(0.0) \\
10(8.1)\end{array}$ \\
\hline $\begin{array}{l}\text { Based on your experience, do you think that all } \\
\text { athletes, parents, and coaches should have to } \\
\text { complete annual concussion education (for } \\
\text { example read a short information sheet or watch a } \\
\text { video?) }\end{array}$ & $\begin{array}{c}\text { Yes } \\
\text { No } \\
\text { Undecided } \\
\text { Blank }\end{array}$ & $\begin{array}{c}89(72.4) \\
18(14.6) \\
8(6.5) \\
8(6.5)\end{array}$ \\
\hline
\end{tabular}


Table 2: Continued

\begin{tabular}{|c|c|c|}
\hline $\begin{array}{l}\text { Questions answered by parents who identified } \\
\text { that their child sustained a suspected } \\
\text { concussion during the study season }(n=20)\end{array}$ & Responses & $\begin{array}{c}\text { Number } \\
n=\mathbf{2 0}(\%)\end{array}$ \\
\hline $\begin{array}{l}\text { After sustaining a suspected concussion, did you } \\
\text { contact the Winnipeg AAA Hockey concussion } \\
\text { protocol coordinator to notify them that your } \\
\text { child had sustained a suspected concussion? }\end{array}$ & $\begin{array}{l}\text { Yes } \\
\text { No }\end{array}$ & $\begin{array}{r}9(45.0) \\
11(55.0)\end{array}$ \\
\hline $\begin{array}{l}\text { After sustaining a suspected concussion, at what } \\
\text { healthcare facility did your child receive medical } \\
\text { care? (check all that apply) }\end{array}$ & $\begin{array}{l}\text { Pediatric ED } \\
\text { Adult ED } \\
\text { Pan Am } \\
\text { Minor } \\
\text { Injury } \\
\text { Pan Am } \\
\text { Concussion } \\
\text { Program } \\
\text { Family/own } \\
\text { physician } \\
\text { Out of town } \\
\text { ED }\end{array}$ & $\begin{array}{l}3(15.0) \\
2(10.0) \\
3(15.0) \\
14(70.0) \\
2(10.0) \\
1(5.0)\end{array}$ \\
\hline $\begin{array}{l}\text { After sustaining a suspected concussion, was your } \\
\text { child assessed by a medical doctor (MD)? }\end{array}$ & $\begin{array}{l}\text { Yes } \\
\text { No } \\
\text { Blank }\end{array}$ & $\begin{aligned} 14 & (70.0) \\
5 & (25.0) \\
1 & (5.0)\end{aligned}$ \\
\hline $\begin{array}{l}\text { After sustaining a suspected concussion, did you or } \\
\text { your child receive guidance about how they } \\
\text { should gradually return to school and sports } \\
\text { activities? }\end{array}$ & $\begin{array}{l}\text { Yes } \\
\text { No } \\
\text { Blank }\end{array}$ & $\begin{array}{c}19(95.0) \\
0(0.0) \\
1(5.0)\end{array}$ \\
\hline $\begin{array}{l}\text { After sustaining a suspected concussion, did your } \\
\text { child return to full hockey games during the } \\
\text { 2016-2017 season? }\end{array}$ & $\begin{array}{l}\text { Yes } \\
\text { No } \\
\text { Blank }\end{array}$ & $\begin{aligned} 18 & (90.0) \\
1 & (5.0) \\
1 & (5.0)\end{aligned}$ \\
\hline $\begin{array}{l}\text { After sustaining a suspected concussion, did your } \\
\text { child receive a doctor's note telling the coach that } \\
\text { they were medically cleared to return to full game } \\
\text { play? }\end{array}$ & $\begin{array}{c}\text { Yes } \\
\text { No } \\
\text { Blank } \\
\text { Don't know } \\
\text { N/A-didn't } \\
\text { return }\end{array}$ & $\begin{aligned} 15 & (75.0) \\
2 & (10.0) \\
1 & (5.0) \\
1 & (5.0) \\
1 & (5.0)\end{aligned}$ \\
\hline $\begin{array}{l}\text { After your child was cleared to return to full game } \\
\text { play, did you or your child provide your child's } \\
\text { coach with a doctor's note indicating your child } \\
\text { had been medically cleared to return to full game } \\
\text { play? }\end{array}$ & $\begin{array}{c}\text { Yes } \\
\text { No } \\
\text { Blank } \\
\text { Don't know } \\
\text { N/A-didn't } \\
\text { return }\end{array}$ & $\begin{aligned} 12 & (60.0) \\
2 & (10.0) \\
2 & (10.0) \\
3 & (15.0) \\
1 & (5.0)\end{aligned}$ \\
\hline
\end{tabular}

\section{DISCUSSION}

This study provides preliminary evidence that adopting and implementing a medically supervised league-wide concussion protocol for youth hockey in Canada is feasible but highlights a number of key factors that must be considered by sport stakeholders when developing these protocols.

First, compliance with standardized concussion protocols is critically dependent on optimizing pre-season education and awareness across all sport stakeholders, as well as ensuring clear communication between medical and sport stakeholders in instances in which athletes are managed through the concussion protocol. Although we found mixed reviews regarding the quality of communication coaches and parents felt they had received from the league about the concussion protocol, the results of our surveys suggest that the vast majority of responding coaches $(90 \%)$ and parents $(91 \%)$ were well aware that there was a standardized concussion protocol in place for the 2016-2017 season. This level of awareness among sport stakeholders was associated with $96.7 \%$ of athletes managed through the concussion protocol being captured by the Concussion Protocol Coordinator and 100\% of eligible athletes undergoing complete medical follow-up and clearance to return to full hockey activities. However, despite dedicated clinical pathways to expedite post-injury concussion care and league investment in a designated Concussion Protocol Coordinator, the results of coach and parent surveys suggest that there were indeed athletes who sustained suspected concussions during the season that were not reported to the concussion protocol coordinator and thus not managed through the concussion protocol. Taken together, the results of this study suggest that medically supervised concussion protocols can be established for youth hockey; however, compliance is difficult to assess and is dependent on sport stakeholder awareness and education, as well as reliable injury recognition and reporting.

Second, the results of this study underscore the importance that all athletes with a suspected concussion undergo medical assessment and medical clearance by a physician. Expert consensus guidelines, as well as standardized concussion protocols in professional sports leagues, consistently recommend that all athletes removed from play with a suspected concussion undergo urgent medical assessment by a physician..$^{9,11,12,16,17}$ To provide comprehensive medical assessment and clearance of athletes with a suspected concussion, a trained clinician must exclude more severe forms of TBI, cervical spine injuries and other medical and neurological disorders and must do so based on features of the clinical history, physical examination findings and the use of diagnostic imaging as needed. ${ }^{7}$ In the majority of Canada, only MDs and nurse practitioners are licensed to perform medical assessments, order diagnostic imaging studies, and initiate referrals to other sub-specialty physicians. A review of clinical and healthcare utilization obtained from this study revealed that most patients who entered the standardized concussion protocol were managed successfully with proper education and supervised progression through their Return-to-Sport strategy. However, a number of patients benefitted from timely access to diagnostic imaging and multi-disciplinary consultation with other healthcare professionals with licensed expertise in vestibular and cervical spine physiotherapy and exercise science. Importantly, follow-up medical assessment in one patient resulted in timely neuroimaging and diagnosis of a previously unrecognized thoracic spine fracture. This important element of the concussion protocol was supported by our survey results where $100 \%$ of coaches and $85.4 \%$ of parents indicated that all athletes with a suspected concussion should be evaluated by a MD. Taken together, we recommend that all established standardized concussion protocols, especially those implemented in high-risk sports such as hockey, require that all athletes with a suspected concussion undergo medical assessment and clearance by a physician (or nurse practitioner) - ideally by one with clinical training and experience in traumatic brain and spine injuries.

Third, the results of this study support previous recommendations from the Canadian Concussion Collaborative that all concussion protocols should undergo a process of periodic review and evaluation. ${ }^{10}$ In addition to providing sport stakeholders the opportunity to assess protocol compliance, feedback from coaches and parents can also help identify areas of the concussion protocol that can be improved. Two aspects of the present concussion protocol that were identified as needing improvement were athlete education and communication between medical professionals and coaches. Although proper identification of athletes with a suspected concussion is highly dependent on athletes recognizing 


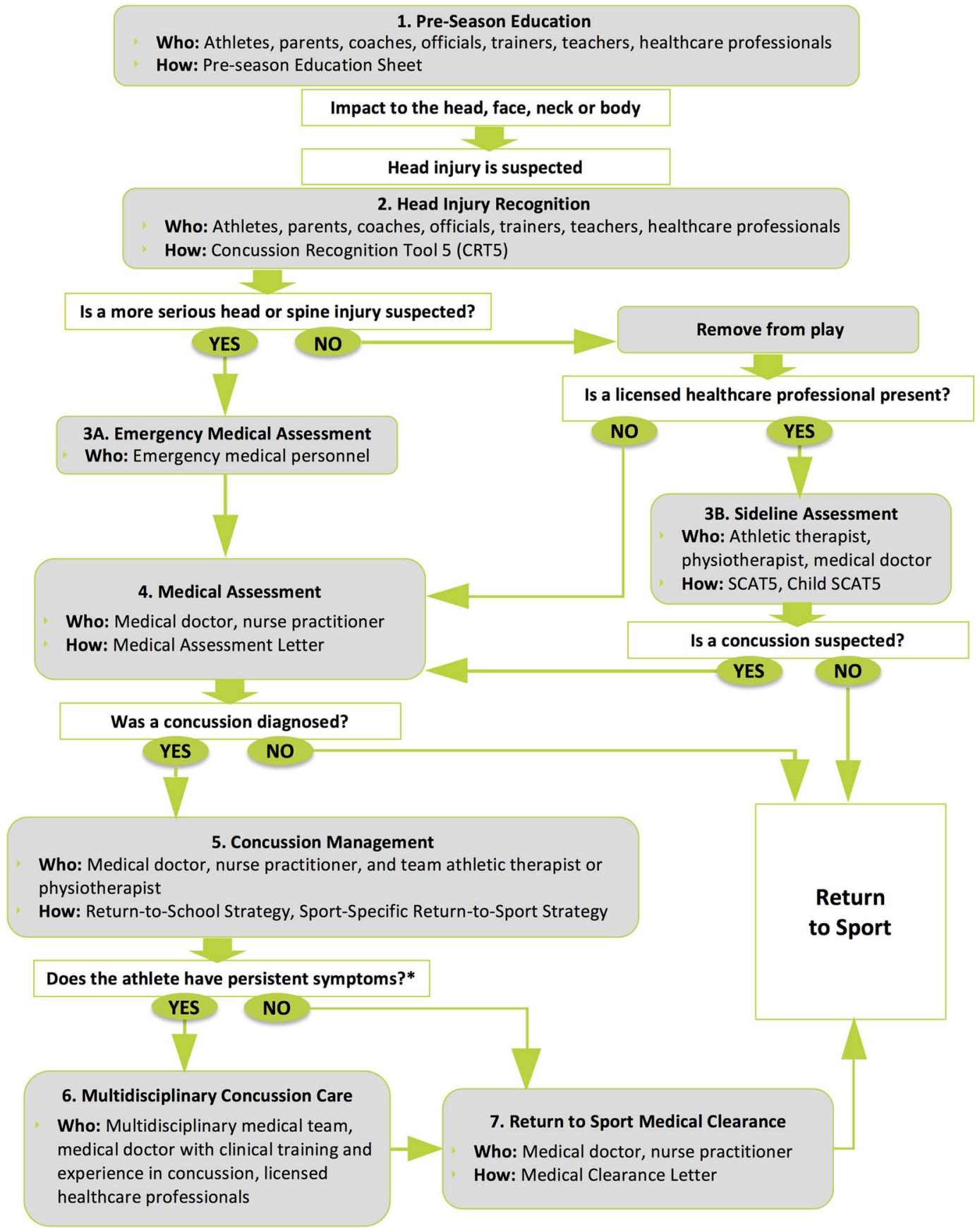

*Persistent symptoms: lasting $>4$ weeks in children \& youth or $>2$ weeks in adults

Figure 1: The Canadian sport concussion pathway (Reproduced with permission from Parachute Canada; Parachute: Canadian Guideline on Concussion in Sport. 2017. www.parachutecanada.org, accessed November $5,2017)$.

and reporting concussion symptoms, historically pre-season sport stakeholder concussion education had not been included as a mandatory component of the concussion protocol. Although survey data indicated that $70 \%$ of coaches and $45.5 \%$ of parents felt that the athletes received enough education on concussion, there was inconsistent support for mandating annual concussion education for all athletes, parents, and coaches. Survey data also suggested that although head coaches received written documentation indicating when an athlete was medically cleared to return to games, communication regarding what activities the athletes were cleared to participate in during the Return-to-Sport process could be improved.

Although the results of this evaluation and review process helped guide future revisions to the Winnipeg AAA Hockey concussion protocol, this process also benefitted from recent work completed on the Concussion Protocol Harmonization Project, a federal government initiative to develop a national guideline on concussion education, prevention, and management in Canada, as 
well as sports-specific concussion protocols for several national sports. ${ }^{18}$ Released in July 2017, the Canadian Guideline on Concussion in Sport outlines a standardized clinical pathway to help guide the development of sport-specific concussion protocols including measures to optimize pre-season sport stakeholder education, injury recognition, and medical assessment and clearance (see Figure 1). ${ }^{11}$ Therefore, to address some of the limitations of the concussion protocol identified in this study and incorporate recommendations from the Canadian Guideline on Concussion in Sport, the 2017-2018 Winnipeg AAA Hockey concussion protocol underwent significant revision including adding a requirement that all athletes, parents, and head coaches complete a standardized pre-season concussion education sheet ${ }^{11}$ (see Supplementary Material). The revised protocol also incorporated the use of the Medical Assessment and Medical Clearance Letters included in the guideline to help improve communication between medical professionals and athletes, parents, coaches, and league organizers.

This study has several important limitations. First, although the survey response rates for head coaches (71.4\%) and parents $(52.8 \%)$ were acceptable, we did not receive responses from all head coaches and parents. Therefore, it is possible that there were additional athletes who sustained a suspected concussion during the study season who were not managed through the standardized concussion protocol. As we did not obtain survey responses from athletes who participated in the 2016-2017 season, there may have also been injuries that were not reported to parents and coaches and thus were not captured. Indeed, under-reporting of concussions remains a persistent concern in youth sports, ${ }^{19,20}$ and future studies assessing compliance with standardized concussion protocols in youth sports should consider including athlete surveys. Second, the coaches and parents who provided post-season feedback on the concussion protocol were aware that the surveys were being undertaken by the pediatric concussion program, which may have influenced responses to certain questions. However, survey recipients were notified that their names or identifying characteristics were not being collected, which should have minimized any pressure to answer questions favorably.

In conclusion, this study suggests that adoption and implementation of a standardized medically supervised concussion protocol for elite youth hockey in Canada is feasible but identifies a number of key elements that should be considered in the development and periodic evaluation of these protocols. This study provides supportive evidence that standardized concussion protocols for high-risk youth sports such as hockey must ensure that all athletes with a suspected concussion have timely access to physicians and multi-disciplinary experts in TBI to ensure comprehensive medical management and safe return to play. Future research is needed to examine whether revisions to the 2017-2018 Winnipeg AAA Hockey concussion protocol lead to enhanced compliance and an improvement in sport stakeholder feedback.

\section{ACKNOWLEDGMents}

The authors would like to thank Russ Cassidy, VP AAA Hockey, Kelsey McCuspey, Concussion Protocol Coordinator, and all coaches and parents for their support of Winnipeg AAA Concussion Protocol and this study.

\section{Discloure}

MJE reports receiving an honorarium from Parachute for his role as co-chair of the Expert Advisory Concussion Subcommittee. $\mathrm{JL}, \mathrm{DMC}, \mathrm{KR}, \mathrm{JK}$, and KFR have nothing to disclose.

\section{CONFlicts OF INTEREST}

MJE is the co-chair of the Expert Advisory Committee for Parachute Canada, a non-profit injury prevention organization, who partnered with the Public Health Agency of Canada and National Sport Organizations to develop the Canadian Guideline on Concussion in Sport. He also represents the Canadian Neurosurgical Society on the Canadian Concussion Collaborative.

\section{Statement of Authorship}

Co-authors MJE and KFR conceptualized and designed the study, drafted the initial manuscript, critically reviewed and revised the manuscript, and approved the final manuscript as submitted. JL, DMC, KR, and JK carried out data collection for the study, critically reviewed and revised the manuscript, and approved the final manuscript as submitted. All authors approved the final manuscript as submitted and agreed to be accountable for all aspects of the work.

\section{SUPPLEMENTARY MATERIAL}

To view supplementary material for this article, please visit https://doi.org/10.1017/cjn.2018.30

\section{REFERENCES}

1. Hockey Canada. 2016, Hockey Canada: 2015-2016 Annual report, 2016. Available at: www.hockeycanada.ca. Accessed November 5, 2017.

2. Emery CA, Meeuwisse WH. Injury rates, risk factors, and mechanisms of injury in minor hockey. Am J Sports Med. 2006;34:1960-9.

3. Harris AW, Voaklander DC, Drul C. Hockey-related emergency department visits after a change in minor hockey age groups. Clin J Sport Med. 2012;22:455-61.

4. Houghton KM, Emery CA. Bodychecking in youth ice hockey. Paediatr Child Health. 2012;17:509-10.

5. Davis GA, Anderson V, Babl FE, et al. What is the difference in concussion management in children as compared with adults? A systematic review. Br J Sports Med. 2017;51:949-57.

6. Williams RM, Puetz TW, Giza CC, Broglio SP. Concussion recovery time among high school and collegiate athletes: a systematic review and meta-analysis. Sports Med. 2015;45: 893-903.

7. Ellis MJ, Ritchie LJ, McDonald PJ, et al. Multidisciplinary management of pediatric sports-related concussion. Can J Neurol Sci. 2017;44:24-34

8. Makdissi M, Cantu RC, Johnston KM, McCrory P, Meeuwisse WH. The difficult concussion patient: what is the best approach to investigation and management of persistent (10 days) postconcussive symptoms? Br J Sports Med. 2013;47:308-13.

9. Cochrane GD, Owen M, Ackerson JD, Hale MH, Gould S. Exploration of US men's professional sport organization concussion policies. Phys Sportsmed. 2017;45:178-83.

10. Fremont P, Bradley L, Tator CH, Skinner J, Fischer LK, Canadian Concussion Collaborative. Recommendations for policy development regarding sport-related concussion prevention and management in Canada. Br J Sports Med. 2015;49:88-9.

11. Parachute. Canadian Guideline on Concussion in Sport, 2017. Available at: www.parachutecanada.org. Accessed November 5, 2017.

12. McCrory P, Meeuwisse WH, Aubry M, et al. Consensus statement on concussion in sport: the 4th International Conference on 
Concussion in Sport held in Zurich, November 2012. Br J Sports Med. 2013;47:250-8.

13. Kontos AP, Elbin RJ, Schatz P, et al. A revised factor structure for the post-concussion symptom scale: baseline and postconcussion factors. Am J Sports Med. 2012;40:2375-84.

14. Lovell MR, Iverson GL, Collins MW, et al. Measurement of symptoms following sports-related concussion: reliability and normative data for the post-concussion scale. Appl Neuropsychol. 2006;13:166-74.

15. Cordingley D, Girardin R, Reimer K, et al. Graded aerobic treadmill testing in pediatric sports-related concussion: safety, clinical use, and patient outcomes. J Neurosurg Pediatr. 2016;25:693-702.

16. Ontario Neurotrauma Foundation. Standards for post-concussion care: from diagnosis to the interdisciplinary concussion clinic, 2017. Available at: www.onf.org. Accessed November 5, 2017.
17. McCrory P, Meeuwisse W, Dvorak J, et al. Consensus statement on concussion in sport-the 5th international conference on concussion in sport held in Berlin, October 2016. Br J Sports Med. 2017;51:838-47.

18. Parachute. Available at: http://www.parachutecanada.org/home/ print/2231/. Accessed November 5, 2017.

19. Register-Mihalik JK, Guskiewicz KM, McLeod TC, Linnan LA, Mueller FO, Marshall SW. Knowledge, attitude, and concussionreporting behaviors among high school athletes: a preliminary study. J Athl Train. 2013;48:645-53.

20. Rivara FP, Schiff MA, Chrisman SP, Chung SK, Ellenbogen RG, Herring SA. The effect of coach education on reporting of concussions among high school athletes after passage of a concussion law. Am J Sports Med. 2014;42:1197-1203. 